\title{
Design of Stirred Tank Reactor for Bioetanol Production from Banana Rod Using Cellulase Enzymes Cow's Liquid Rumen
}

Qurrotun A'yuni Khoirun Nisa', ${ }^{1}$ Vita Paramita ${ }^{1}$

\begin{abstract}
Due to pandemic, supply of alcohol as desinfectant really needed for nowadays. This research aims to determine the levels of bioethanol produced from banana rods by the hydrolysis process. The target to be achieved with the reactor design is to achieve high ethanol purity using a first order reaction kinetics approach. The study was carried out on various variables including fermentation time ( 6 - 30 hours), hydrolysis temperature $\left(80-90^{\circ} \mathrm{C}\right.$ ), and substrate enzyme ratio (1:1 $-1: 3)$. While the parameters to be tested are glucose levels and bioethanol levels. The optimal effect of the variable on alcohol content is obtained when the lalcohol content value is more than $17.2 \%$ with an enzyme ratio of 3 3.5 at a temperature of $94-96{ }^{\circ} \mathrm{C}$ for $35-40$ hours. From the research, it was found that it is possible to enlarge the reactor up to 10000 times by using a ratio ratio to obtain the ideal stirred tank reactor dimensions with a conversion of $97.15 \%$.
\end{abstract}

Keywords: Banana rod, Bioethanol, Fermentation, Hydrolisis

\section{Introduction}

The pandemic, which now almost spread world wide caused by the corona virus (COVID-19), become one of the big concerns. One of the things affected is a change in health behavior, including the consumption of alcohol. Alcohol $70 \%$ as a desinfectant is increasingly needed, ethanol can kill bacteria by rapid denaturation of proteins and membranes, resulting in subsequent interference with metabolism and cell lysis (Strunk et al. 2011). Bioethanol is kind of alcohol that can be produced from lignocellulose such as agricultural, wood and plant waste containing starch or carbohydrates, and then converted into water-soluble glucose (Chittibabu. 2011). After obtaining glucose, then it is processed into ethanol by a fermentation process. Ethanol fermentation is the activity of breaking down sugars (carbohydrates) into ethanol compounds by releasing $\mathrm{CO}_{2}$ gas. One of the alternative biomass for bioethanol is banana stem. So far, banana stems are not widely used and will only become waste. Banana tree waste is one of the potential sources of ethanol with a method that can be developed continuously and with low production costs (Bello et al. 2014). This study aims to determine the level of ethanol produced in banana rod fermentation using the Saccharomyces cereviciae bacteria in a stirred tank reactor. Another objective is to obtain the ideal reactor design from reaction kinetics. Currently, studies on the subject of bioethanol production from biomass have been carried out such as banana weevil fermentation with Saccharomyces cereviceae can also produce bioethanol (Ingale et al. 2011) Banana tree waste is one of the potential sources of ethanol with a method that can be developed continuously and with low production $\operatorname{costs}^{3}$. This research was conducted to determine the potential of banana rods as an alternative biomass for producing bioethanol.

*Correspondence: vitaparamita@gmail.com

${ }^{1}$ Chemical Engineering Department, Vocational School of Diponegoro University Prof Sudarto SH street, Pedalangan

Tembalang, Semarang 50239, Indonesia 


\section{Materials and methods}

The research materials were banana rod, distilled water, Sacchromyces cerevisiae, cellulase enzymes and urea. Banana rod were obtained from the banana plantation park of Diponegoro University, while for the preparation of cellulase enzymes obtained from the rumen of cows in the slaughter house of Semarang, Central Java and isolated in the Biology Laboratory of the State University of Semarang by filtration under cold condition. The raw material preparation process starts with the isolation of cellulose from the banana rod. Then, the hydrolysis process is carried out biologically using cellulase enzymes from the cow's rumen. The hydrolyzed solution was then fermented using the help of Sacchromyces cerevisiae. At this stage of the analysis includes total glucose conversion and alcohol content. The process schematic is depicted in Figure 1 using the Aspen Hysys application version 8.8.

Optimization of the process of making bioethanol using a stirred tank reactor with banana rod samples. The variables used in the practicum are independent variables and dependent variables. independent variables include temperature, time, and enzyme ratio. While the dependent variable includes total alcohol and glucose levels.

\section{Results and discussions Growth of Saccharomyces cereviceae}

Saccharomyces cereviceae used as an inoculum with a total of $10^{6} \mathrm{CFU} / \mathrm{ml}$. Saccharomyces cereviceae were cultured using the Total Plate Count (TPC) method with a $10^{-2}$ dilution using physiological salts.

From figure 2, the value of $\mathrm{k}=0.8681$ is obtained.

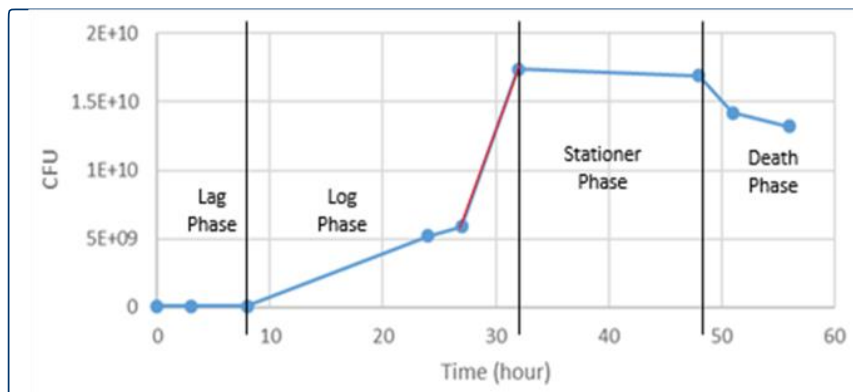

Fig 2. Growth of Saccharomyces cereviceae

The data is taken by determining the highest slope (hour 27 - 32) in order to obtain the number of splits per unit time is 0.31206 / hour with the splitting of 2.496481 times. The average doubling time was 2.002819 hours. Saccharomyces cereviceae have doubling time approximately $90 \mathrm{~min}$ (Friedman, 2011. Herskowitz, 1988. Kaeberlein, 2005. Kaeberlein, 2010), in $30{ }^{\circ} \mathrm{C}$ or

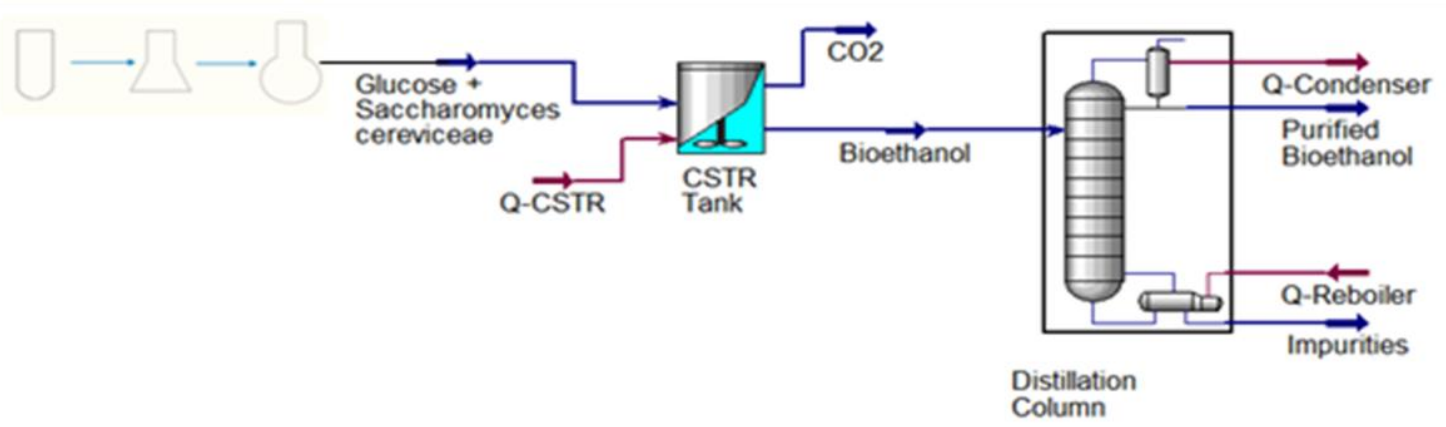

Fig 1. Bioethanol production process scheme

Determination of variables using central composite design (Yulianto et al. 2018) on Response Surface Methodology (RSM) standard design factor / block / run: 3/1/16. The first step is to determine a summary for variable consisting of temperature with the lowest value, namely $80^{\circ} \mathrm{C}$; the middle value is $85^{\circ} \mathrm{C}$ and the highest value is $90^{\circ} \mathrm{C}$. The second step determines the time with the lowest value of 10 hours; the middle value is 20 hours and the highest value is 30 hours. The third step is to determine the enzyme ratio with the lowest value, namely 1 ; The middle value is 2 and the highest value is 3 . In this experiment, the alpha for rotatability calculation is 1.6818. After the variables from the RSM method are obtained, proceed with the practicum process. Before the hydrolysis and fermentation processes, previously carried out the isolation process of cellulase from the rumen of cows and cellulose from banana rods.
$86{ }^{\circ} \mathrm{F}$ their doubling time is $1.25-2$ hours (Boekhout, 2003).

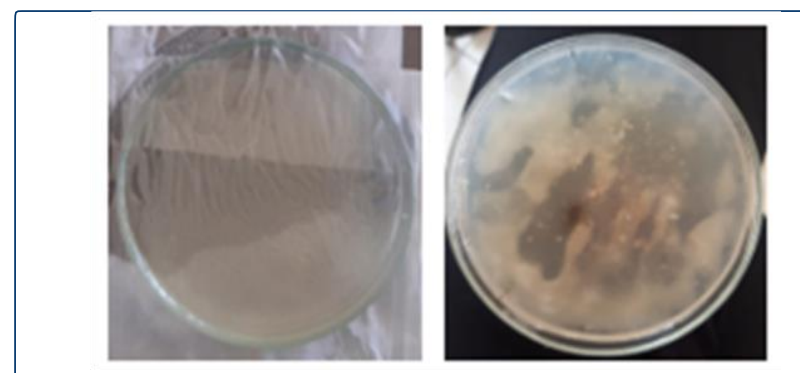

Fig 3. Growth of Saccharomyces cereviceae significant in hour $27-32$

\section{Glucose content}

Testing the total glucose content begins with the absorbance test of the bioethanol solution using the Genesys 20 Spectrophotometer in $540 \mathrm{~nm}$. Cellulase 
enzyme that isolated from rumen liquid under cold condition shows a high activity of enzyme (Paramita et al. 2015) that use in hydrolisis process. From the standard curve is obtained it can be obtained average of glucose content is around 1,494 $\pm 0,007$. Glucose is phosphorylated in two stages. Two ATPs are used to produce fructose 1,6 dysphosphate, which is then broken down by the enzyme aldolase to form two 3carbon triose phosphates. Inorganic phosphate is assimilated into two triose diphosphates from which four $\mathrm{H}$ atoms are accepted by the two oxidized NAD molecules. Finally, four ATPs are formed by the transfer of phosphate from triose diphosphate to ADP which results in the formation of two pyruvic acid molecules. Some pyruvic acid and other intermediates are used by yeast cells via various metabolic pathways as building blocks for new yeast cells and some glycerol is made from an intermediate material, dihydroxyacetone. However, most of the pyruvic acid is immediately converted to ethanol and carbon dioxide (Jacques et al. 1999).

\section{Alcohol content}

Research to determine alcohol content using the specific gravity of the sample using a ratio between the density of the substance and water at a temperature of $60^{\circ} \mathrm{F}$, then calculating the alcohol content using the content table of the mixture of $\mathrm{C}_{2} \mathrm{H}_{5} \mathrm{OH}$ and water in tables $2-112$ (Perry et al. 2008).
, $063412438753933 * \mathrm{x}-, 00040367857425189 * \mathrm{x}^{2}-$ $1,1333289756657 * \mathrm{y}+, 072786180860938^{*} \mathrm{y}^{2}+, 000927$ $97515045627 * 84,62925 * x+, 0092797515045633 * 84,6$ $2925 * \mathrm{y}-, 0056202679091437 * \mathrm{x} * \mathrm{y}-3,2438715$

In Figure 4 (a) it is known that the optimum alcohol content value of more than $17.2 \%$ is achieved at an enzyme ratio of $3-3.5$ with a length of time between 35 - 40 hours. Figure 4 (b) shows the relationship between total glucose content, temperature and enzyme ratio. By applying multiple regression analysis to experimental data, a second level polynomial equation is obtained:

$$
\begin{gathered}
\mathrm{Z}(\mathrm{x}, \mathrm{y})=20,492626362494- \\
, 076526586975219 * \mathrm{x}+, 00045133572925656^{*} \mathrm{x}^{2}- \\
1,1333289756657 * \mathrm{y}+, 072786180860938 * \mathrm{y}^{2}+, 0009279 \\
7515045627 * 20,{ }^{*} \mathrm{x}+, 0092797515045633^{*} \mathrm{x} * \mathrm{y}- \\
, 0056202679091437 * 20,{ }^{*} \mathrm{y}-1,4297202
\end{gathered}
$$

In Figure 4 (b) it is known that the optimum alcohol content value reaches more than $17.2 \%$ at a temperature of $80-85 \circ \mathrm{C}$ with an enzyme ratio of 3 3.5. Figure 4 (c) shows the relationship between alcohol content, temperature and time. By applying multiple regression analysis to experimental data, a second level polynomial equation is obtained to represent the total glucose content obtained as follows:

$\mathrm{Z}(\mathrm{x}, \mathrm{y})=20,492626362494-$

, $076526586975219 * \mathrm{x}+, 00045133572925656 * \mathrm{x} 2$

$, 063412438753 * \mathrm{y}, 00040367857425189 * \mathrm{y} 2+, 000927$

$97515045627 * \mathrm{x} * \mathrm{y}+, 00927975150 * 1,999375 * \mathrm{x}-$ $, 0056202679091437 * 1,999375 * \mathrm{y}-1,9749868$

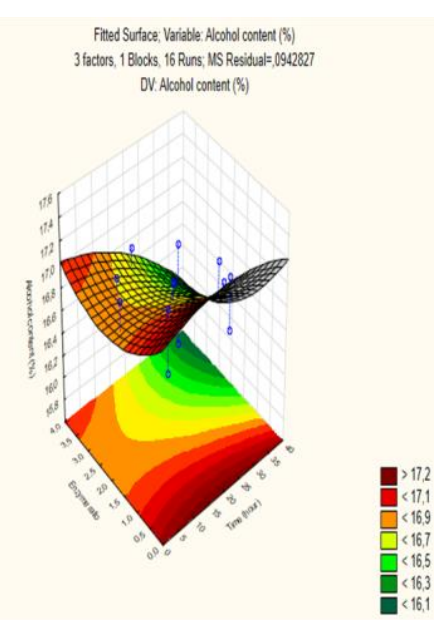

(a)

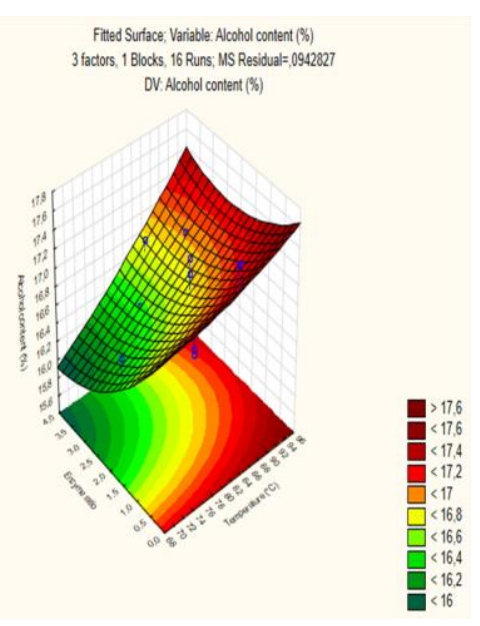

(b)

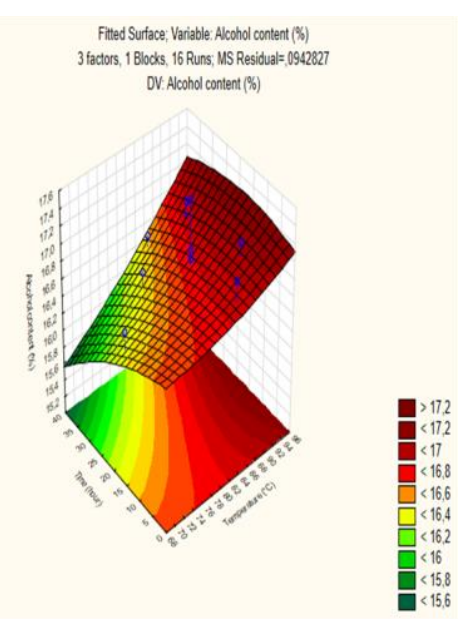

(c)

Fig 4. The response fitted surface variable temperature, time, and enzyme ratio to the alcohol content response

From the experimental results, a response fitted surface can be created in Figure 4 (a). Figure 4 (a) shows the relationship between alcohol content, time and enzyme ratio. By applying multiple regression analysis to experimental data, a second level polynomial equation is obtained to represent the total glucose content obtained as follows:

$$
\mathrm{Z}(\mathrm{x}, \mathrm{y})=20,492626362494-
$$

In Figure 4 (c) it is known that the optimum alcohol content reaches more than $17.2 \%$ at temperatures between $80-85{ }^{\circ} \mathrm{C}$ with a length of time between 35 40 hours. Thus, it can be concluded that the optimum conditions for variable influence on alcohol content are obtained when the alcohol content value is more than $17.2 \%$ with an enzyme ratio of $3-3.5$ at a temperature of $80-85{ }^{\circ} \mathrm{C}$ for 35 - 40 hours. 
Process optimization for the production of bioethanol from banana rod was carried out through 16 experiments using temperature, time, and enzyme ratio dependent variables. The $t$ test value indicates a value greater than the $p$ value. The accuracy of this model can be determined from the coefficient of determination $\left(\mathrm{R}^{2}\right)$. The $\mathrm{R}^{2}$ value represents a measure of how much variability in the observed response values can be explained by the experimental variables and their interactions. From the $\mathrm{R}^{2}$ value, it can be concluded that the estimated value by the model is close to the value obtained from the experimental results. The value of $\mathrm{R}^{2}$ is always between 0 and 1 . The closer the $R^{2}$ value is to 1 , indicating that the model is good at predicting responses, it is stated that $\mathrm{R}^{2}$ higher than 0.90 is considered as the indication of the model high correlation (Wang et al. 2015). In this case, the coefficient of determination $\left(\mathrm{R}^{2}=0.94314\right)$ indicates that $94.31 \%$ of the variability in response can be explained by the model (Table 1).

Table 1 Summary effect estimates

\begin{tabular}{lcc}
\hline \multicolumn{1}{c}{ Factor } & Effect & $\begin{array}{c}\text { Standar } \\
\text { error }\end{array}$ \\
\hline (1) Temperature $\left({ }^{\circ} \mathrm{C}\right)(\mathrm{L})$ & 0,42711 & 0,107660 \\
Temperature $\left({ }^{\circ} \mathrm{C}\right)(\mathrm{Q})$ & 0,02119 & 0,007403 \\
(2) Time (hour) $(\mathrm{L})$ & 0,29396 & 0,093875 \\
Time (hour) $(\mathrm{Q})$ & 0,21013 & 0,113363 \\
(3) Enzymes ratio $(\mathrm{L})$ & 0,58346 & 0,093803 \\
Enzymes ratio (Q) & 0,17361 & 0,112953 \\
$1 \mathrm{~L}$ by 2L & $-0,09457$ & 0,122654 \\
$1 \mathrm{~L}$ by 3L & $-0,01182$ & 0,122654 \\
2L by 3L & 0,24448 & 0,122654 \\
\hline Average & 0,20528 & 0,099669 \\
$\mathrm{R}^{2}$ & \multicolumn{2}{c}{0,94314} \\
\hline
\end{tabular}

The proximity of the estimated values to the model is close to the values obtained from the experimental results shown in Figure 5. The plot values in the graph show a satisfactory correlation between the experimental and estimated values, because the deviation between the experimental and estimated values is close to the linear line. The regression coefficient can be clarified by means of the Pareto diagram (Figure 6) for each variable.

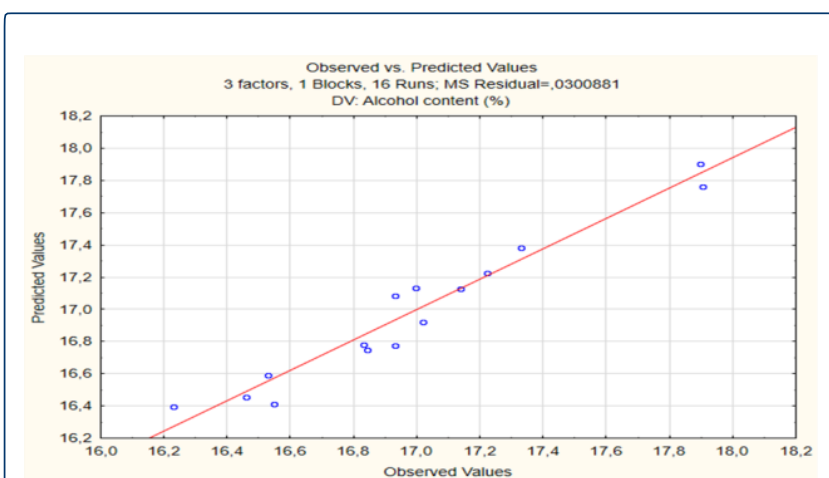

Fig 5. Comparison of experimental data and estimated alcohol content

From the block diagram, it appears that the dependent variable that has the most influence in the process of making bioethanol from banana rod is the enzyme ratio indicated by higher value of independent parameter value than 0,05 as the $p$ value (Paramita et al. 2019).

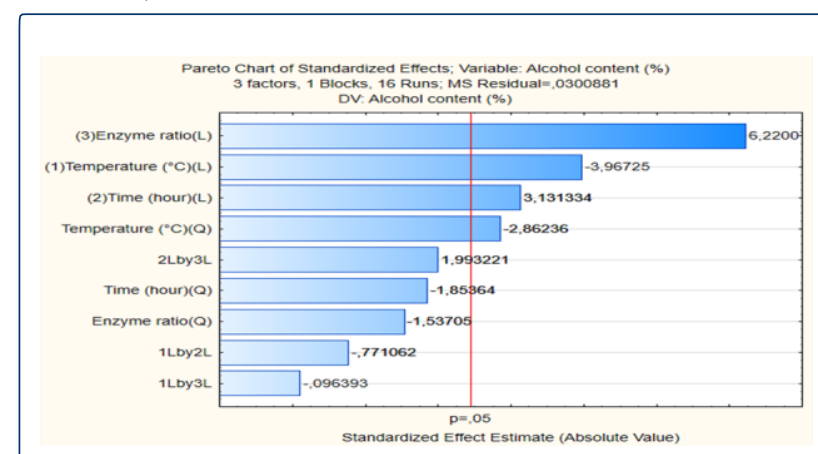

Fig 6. Pareto diagram of the effect of variables on alcohol content

The results of the response surface model are in the form of Analysis of Variance (ANOVA) which is given in Table 8. ANOVA is needed to test the significance and adequacy of the model. The Fisher ratio of variance, the value of $F\left(=S_{r}^{2} / S^{2}\right)$, is a statistically valid measure of how well the factors explain variations in the mean data and the effect of the predicted real factors. The greater the $\mathrm{F}$ value, the more uniformity it is. The ANOVA of the regression model shows that this model shows a correlation ${ }^{15}$, as evidenced by the $\mathrm{F}$ value of the Fisher test (Fmodel $=$ 82.801).

Table 2 Analysis of variants of the polynomial equation model for the production of banana rod bioethanol

\begin{tabular}{lcccl}
\hline \multicolumn{1}{c}{ Factor } & SS & df & \multicolumn{1}{c}{ MS } & \multicolumn{1}{c}{$\mathbf{F}$} \\
\hline (1) Temperature $\left({ }^{\circ} \mathrm{C}\right)(\mathrm{L})$ & 0.473 & 1 & 0.473 & 15.739 \\
Temperature $\left({ }^{\circ} \mathrm{C}\right)(\mathrm{Q})$ & 0.246 & 1 & 0.246 & 8.193 \\
(2) Time (hour) $(\mathrm{L})$ & 0.295 & 1 & 0.295 & 9.805 \\
Time (hour) $(\mathrm{Q})$ & 0.103 & 1 & 0.103 & 3.435 \\
(3) Enzyme ratio $(\mathrm{L})$ & 1.164 & 1 & 1.164 & 38.689 \\
Enzyme ratio $(\mathrm{Q})$ & 0.071 & 1 & 0.071 & 2.362 \\
1L by 2L & 0.017 & 1 & 0.017 & 0.594 \\
1L by 3L & 0.000 & 1 & 0.000 & 0.009 \\
2L by 3L & 0.119 & 1 & 0.119 & 3.972 \\
Error & 0.180 & 6 & & \\
\hline Total & 3.174 & 15 & & 82,801 \\
\hline
\end{tabular}

Optimization parameters of alcohol content in bioethanol from the saddlepoint banana rod against temperature, time, and enzyme ratio were determined by a critical value. Thus, the critical value for optimization of alcohol content is achieved at a temperature of $84.47908^{\circ} \mathrm{C}$ for 20.39485 hours with an enzyme ratio of 2.56383 .

Table 3 Predicted values for optimum alcohol content at critical values of temperature, time \& enzyme ratio

\begin{tabular}{lccc}
\hline \multicolumn{1}{c}{ Factor } & $\begin{array}{c}\text { Observed } \\
\text { minimum } \\
\text { value }\end{array}$ & $\begin{array}{c}\text { Critical } \\
\text { value }\end{array}$ & $\begin{array}{c}\text { Observed } \\
\text { maximum } \\
\text { value }\end{array}$ \\
\hline Temperature $\left({ }^{\circ} \mathrm{C}\right)$ & 70,65910 & 84,47908 & 93,40890 \\
Time (hour) & 3,18207 & 20,39485 & 36,81793 \\
Enzyme ratio & 0,31 & 2,56383 & 3,68000 \\
\hline Estimated value of & \multicolumn{4}{c}{16,70644} \\
alcohol content & (with the solution: saddlepoint) \\
(\%) & \multicolumn{3}{|}{} \\
\hline
\end{tabular}

Scale up continuous stirred tank reactor

The scale-up process for this reactor algorithm is as 
follows:

Integration of yield equation (Fogler et al. 1999)

$$
\ln \frac{\mathrm{C}_{\mathrm{A} 0}}{\mathrm{C}_{\mathrm{A}}}=\mathrm{kt}
$$

For the formation of bioethanol (B), the equation becomes (Fogler et al. 1999):

$$
\ln \frac{\mathrm{C}_{\mathrm{A} 0}-\mathrm{C}_{\mathrm{B}}}{\mathrm{C}_{\mathrm{A} 0}}=\mathrm{kt}
$$

Finding the value of the reaction rate constant $(\mathrm{k})$ using semilogarithmic graph analysis. The plot of $\ln \frac{C_{A 0}-C_{B}}{C_{A 0}}$ as a function of time $(\mathrm{t})$ will form a straight line with a slope of $-\mathrm{k}$. Then plot the value $\frac{C_{A 0}-C_{B}}{C_{A 0}}$ against time (t) on a semi-logarithmic scale in the reaction rate analysis, where the slope value of this linear equation will be equal to - $\mathrm{k}$.
Table 4 Calculation on scale up pilot plant for CSTR

\begin{tabular}{ccccc}
\hline $\begin{array}{c}\text { Magnification } \\
\text { (times) }\end{array}$ & $\begin{array}{c}\mathrm{V}_{2} \\
\left(\mathrm{ml}^{3}\right)\end{array}$ & $\mathrm{R}$ & $\begin{array}{c}\mathrm{D} \text { T2 } \\
(\mathrm{m})\end{array}$ & $\mathrm{N}_{2}$ \\
\hline 10 & 11111,11111 & 3,333333 & 0,35 & 210 \\
100 & 111111,1111 & 33,33333 & 3,5 & 21 \\
1000 & 1111111,111 & 333,3333 & 35 & 2,1 \\
10000 & 11111111,11 & 3333,333 & 350 & 0,21 \\
\hline
\end{tabular}

\section{Conclusion}

Optimization of the process of making bioethanol using a stirred tank reactor with banana rod samples. The variables used in the practicum are independent variables and dependent variables. independent variables include temperature, time, and enzyme ratio. While the dependent variable includes total alcohol and glucose levels. The optimum conditions for variable influence on alcohol content are obtained when the

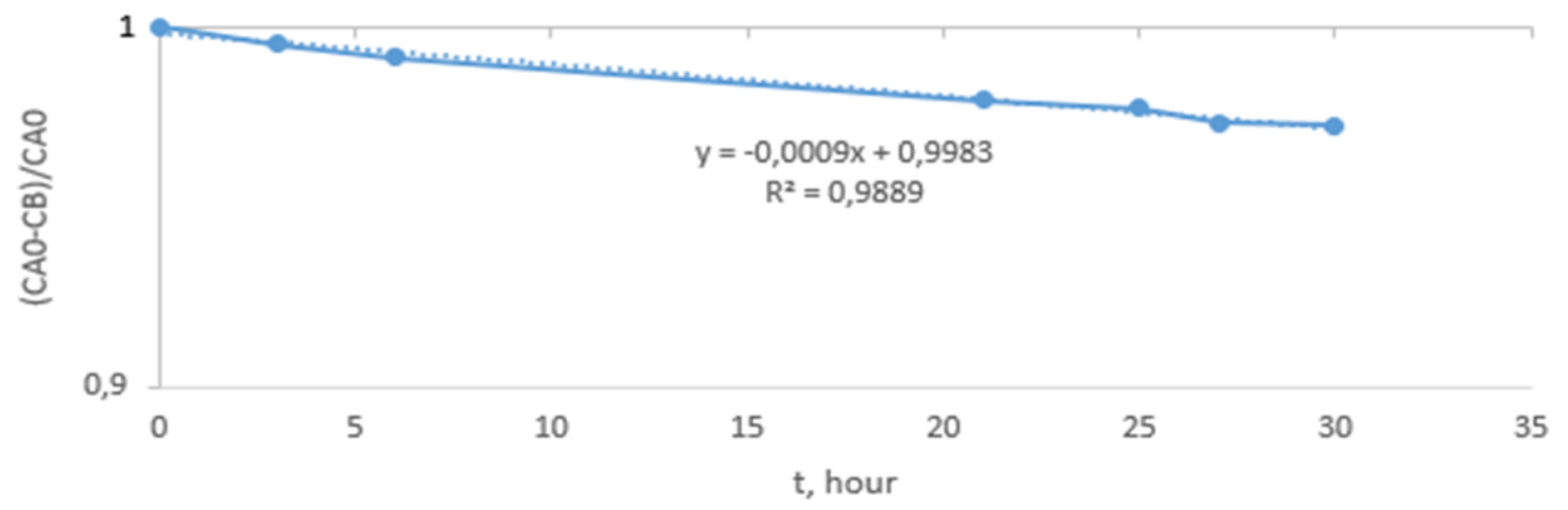

Fig 7. Figure 7. Semilogarithmic graph of the relationship between value $\frac{C_{A 0}-C_{B}}{C_{A 0}}$ against time

From Figure 7 , it is obtained a straight line equation $y=-0.0009 x+0.9983$ so that it can be seen that the slope $(-\mathrm{k})$ of the graph is -0.0009 . The value of the reaction rate constant $(\mathrm{k})$ is 0,0009 , the reaction rate for the formation of bioethanol becomes: $r_{B}=$ $\left(0,0009\right.$ hour $\left.^{-1}\right) \mathrm{C}_{\mathrm{B}}$. The calculation of the scale up to a pilot plant scale algorithm ${ }^{17}$ :

Calculating the scale up ratio (R). Determining laboratory scale volume using equation for residence time $(\tau)=\frac{C_{B}-C_{B 0}}{-r}(3)$, obtained $\mathrm{V}_{1}=1111,111 \mathrm{ml}^{3}, \mathrm{~N}_{1}$ $=700 \mathrm{rpm} . \mathrm{D}_{\mathrm{T} 1}=0.0105 \mathrm{~m}$. Ideal tank, $\mathrm{D}_{\mathrm{T} 1}=\mathrm{H}_{1}$

$$
\mathrm{V}_{1}=\left(\frac{\pi \mathrm{D}_{\mathrm{T} 1}^{2}}{4}\right)\left(\mathrm{H}_{1}\right)=\left(\frac{\pi \mathrm{D}_{\mathrm{T} 1}^{3}}{4}\right)
$$

Volume ratio:

$$
\begin{aligned}
& \frac{\mathrm{V}_{2}}{\mathrm{~V}_{1}}=\frac{\pi \mathrm{D}_{\mathrm{T} 2}^{3} / 4}{\pi \mathrm{D}_{\mathrm{T} 1}^{3} / 4}=\frac{\mathrm{D}_{\mathrm{T} 2}^{3}}{\mathrm{D}_{\mathrm{T} 1}^{3}} \\
& \mathrm{R}=\left(\frac{\mathrm{V}_{2}}{\mathrm{~V}_{1}}\right)^{1 / 3}=\frac{\mathrm{D}_{\mathrm{T} 2}}{\mathrm{D}_{\mathrm{T} 1}}
\end{aligned}
$$

Using $\mathrm{R}$ values for the new dimension: $\mathrm{D}_{\mathrm{a} 2}=\mathrm{RD}_{\mathrm{a} 1}$. Determine the stirring speed for the new geometry $\left(\mathrm{N}_{2}\right)$ from the small-scale stirring results $\left(\mathrm{N}_{1}\right)$

$$
\mathrm{N}_{2}=\mathrm{N}_{1}\left(\frac{1}{\mathrm{R}}\right)^{\mathrm{n}}=\mathrm{N}_{1}\left(\frac{\mathrm{D}_{\mathrm{T} 1}}{\mathrm{D}_{\mathrm{T} 2}}\right)^{\mathrm{n}}
$$

$\mathrm{n}=1$; for the same fluid movement alcohol content value is more than $17.2 \%$ with an enzyme ratio of $3-3.5$ at a temperature of $80-85{ }^{\circ} \mathrm{C}$ for 35-40 hours. Optimization parameters of alcohol content in bioethanol from the saddlepoint banana rod against temperature, time, and enzyme ratio were determined by a critical value. Thus, the critical value for optimization of alcohol content is achieved at a temperature of $84.47908{ }^{\circ} \mathrm{C}$ for 20.39485 hours with an enzyme ratio of 2.56383. The calculation of the scale up to a pilot plant scale is based on the book Basic Principles and Calculations in Chemical Engineering, Himmelblau, 1974 it is found that it is possible to enlarge the reactor up to 10000 times by using a ratio ratio to obtain the ideal stirred tank reactor dimensions with a conversion of $97,15 \%$.

\section{Acknowledgements}

The author grateful to the Laboratory of Chemical Analysis, Diponegoro University and Laboratory of Biology, State University Semarang.

\section{Authors contributions}

This experimental work, data collection, data analysis, illustrations, and manuscript preparation were completed by Qurrotun A'yuni Khoirun Nisa'.

\section{Funding}

Not applicable. 

author.

\section{Ethics approval and consent to participate}

Not applicable.

\section{Consent for publication}

All authors agreed with this publication.

\section{Competing interests}

There are not competing interests

\section{References}

Bello, R.H., Linzmeyer, P., Franco, C.M.B., Souza, O., Sellin, N., Medeiros, S.H.W., Marangoni, C., 2014. Pervaporation of ethanol produced from banana waste. Waste Manag. 34 https://doi.org/10.1016/j.wasman.2014.04.013

Boekhout, T.; Robert, V., eds. (2003). Yeasts in Food: Beneficial and Detrimental aspects. Behr's Verlag. p. 322. ISBN 978-386022-961-3. Retrieved January 10, 2011.

Chittibabu, S., Rajendran, K., Santhanmuthu, M., 2011. Optimization of microwave assisted alkali pretreatment and enzymatic hydrolysis of Banana pseudostem for bioetanol production. 2nd Int. Conf. Environ. Sci. Technol. IPCBEE 6, 67-71.

Fogler, H. Scott. Elements of Chemical Reaction Engineering. Upper Saddle River, N.J. Prentice Hall PTR, 1999.

Friedman N. The Friedman Lab Chronicles. Growing yeasts (Robotically) Nir Friedman Lab. 2011 [Google Scholar]

Herskowitz I. Life cycle of the budding yeast Saccharomyces cerevisiae. Microbiol Rev. 1988;52(4):536-53

Himmelblau, David M., and James B. Riggs. 2012. Basic principles and calculations in chemical engineering. Upper Saddle River, NJ: Prentice Hall.

Ingale, S., Joshi, S.J., Gupte, A., 2014. Production of bioetanol using agricultural waste: Banana pseudo stem. Brazilian J. Microbiol. 45, 885-892. https://doi.org/10.1590/S151783822014000300018

KA. Jacques, TP. Lyons, DR. Kelsall, 4th Ed, The Alcohol Textbook, Distillery Quality Control, Chapter 20, Nottingham University Press, Nottingham, United Kingdom, 1999

Kaeberlein M, Powers RW, Steffen KK, Westman EA, Hu D, Dang N, et al. Regulation of yeast replicative life span by TOR and Sch9 in response to nutrients. Science. 2005;310(5751):1193-6. doi: 10.1126/science.1115535.

Kaeberlein M. Lessons on longevity from budding yeast. Nature. 2010;464(7288):513-9. doi: 10.1038/nature08981.

M.E. Yulianto, V. Paramita, I. Hartati, R. Amalia. 2018.

Response Surface Methodology of Pressurized Liquid Water Extraction of Curcumin from Curcuma Domestica Val. Rasayan Journal of Chemistry. DOI: 10.31788/RJC.2018.1141990

Paramita, V., et al. Effect of immobile isolated enzymes from rumen liquid by using alginate matrices on the bay leaf extraction. AIP Conference Proceedings 1699, 060009 (2015); doi: $10.1063 / 1.4938363$

Paramita, V., Yulianto, M.E., Hartati, I., Bahrudin, U., and Broto, RTD.W.(2019). Optimization On Subcritical Fluid Extraction of Zingiberene. Journal of Vocational Studies on Applied Research, 1(1), 18-21. doi: http://dx.doi.org/10.14710/jvsar.1.1.2019.18-21

Perry, Robert H., and Don W. Green. 2008. Perry's chemical engineers' handbook. New York: McGraw-Hill.

S. Wang. T. You. F. Xu. J Chen. and G. Yang. Bioresources. 10, 4 (2015)

Strunk, Tobias, et al. "Method of bacterial killing differentially affects the human innate immune response to Staphylococcus epidermidis." Innate immunity 17.6 (2011): 508-516. 